\title{
СИСТЕМА ДЕРЖАВНОГО УПРАВЛІННЯ У ВОСННІЙ СФЕРІ В ПІДГОТОВЦІ ДЕРЖАВИ ДО ОБОРОНИ
}

\section{Устименко О. В.}

\section{ВСТУП}

Особливе місце у загальній теорії державного управління посідає іiі розділ, який стосується державного управління у воєнній сфері. Оскільки теорія державного управління в Україні перебуває на стадії активного формування, то цей стан $\epsilon$ характерним і для воєнної сфери. 3 причини, що натепер теоретичні основи державного управління у воєнній сфері опрацьовані не досить повно, в офіційних документах різного рівня, які $є$ методологічною основою для практики, часто трапляється нечіткість та неоднозначність деяких визначень та формулювань. Таке призводить до неадекватних практичних дій, зокрема, в управлінні воєнною сферою, і це є проблемою.

Вітчизняні вчені і фахівці приділяють увагу проблемі розвитку теорії державного управління у воєнній сфері, зокрема іiі понятійнокатегорійного апарату. Однак законодавством України дотепер не визначені часто вживані та принципово важливі терміни «воєнна сфера» та «сфера оборони», а також залежне від них поняття «державне управління у воєнній сфері», що перешкоджає адекватному розумінню сутності системи державного управління у цій сфері. Для адекватного розгляду питань державного управління у воєнній сфері першочергово необхідно визначитися стосовно розуміння сутності термінів «воєнна сфера» та «сфера оборони», їх характерних рис і особливостей та взаємозв'язку.

\section{1. Поняття термінів}

Розпочнемо $з$ поняття терміна «воєнна сфера». У законодавчих актах України (Законі України «Про національну безпеку України», Воєнній доктрині України, Концепції розвитку сектору безпеки і оборони України, Стратегічному оборонному бюлетені України, Стратегії національної безпеки України) поряд 3 терміном «воєнна сфера» використовуються терміни: «сфера воєнної безпеки», «сфера оборони», «сфера національної безпеки і оборони», «сфера воєнної політики», «воєнно-економічна сфера», «військово-технічна сфера», «сфера військового будівництва» тощо. Більше того, в статті 28 Закону України «Про національну безпеку України» однозначно розділено три 
сфери - воєнну, оборони, військового будівництва. Але ні у цьому Законі, ні в інших законодавчих актах України не знаходимо визначень цих термінів, що перешкоджає розумінню теоретичних та практичних механізмів їх застосування роздільно.

Між тим зауважимо, що визначення терміна «воєнна сфера» вже досить давно надано у військових стандартах, але, на жаль, у різних редакціях. Так, у військовому стандарті ВСТ 01.004.001 - 2004 «Воєнна безпека. Основні положення» визначено: «воєнна сфера - сфера діяльності суб'єктів забезпечення національної безпеки щодо захисту національних інтересів від потенційних i реальних зовнішніх та внутрішніх воєнних загроз; частина сфери життєдіяльності особистості, суспільства і держави, яка пов'язана із забезпеченням воєнної безпеки». У військовому стандарті ВСТ 01.004.002 - 2007 «Воєнна безпека. Стратегічне планування. Терміни та визначення» зазначено: «воєнна сфера - усі аспекти, пов'язані 3 будівництвом, підготовкою та діяльністю збройних сил у мирний та воєнний час, а також підготовка населення до війни, збройного конфлікту» ${ }^{1}$.

Обидві дефініції мають певні вади, які висвітлено у ході щорічної Всеукраїнської науково-практичної конференції з міжнародною участю «Нституалізація публічного управління в Україні в умовах євроінтеграційних та глобалізаційних викликів». У першому визначенні допущено подвійне тлумачення цього терміна, а також наявна тавтологія: «воєнна сфера - сфера...», а у другому визначенні повне узагальнення стосується лише збройних сил, хоча необхідно розглядати всі складники, які дотичні до оборони держави у будь-який час.

На наш погляд, з позиції України, яка не лише декларує миролюбну політику, а й реально проводить іiі стосовно інших держав, поняття «воєнна сфера» та «сфера оборони» $є$ синонімічними, отже, тотожними, оскільки пов'язані із сутністю війни та потребами обов'язкового використання зброї для захисту свого державного суверенітету та територіальної цілісності.

Для більшої переконливості розглянемо сутність термінів «війна» та «оборона». Війна - організована збройна боротьба між двома або декількома державами або суспільними класами.

Для умов України в широкому розумінні: оборона - система політичних, економічних, соціальних, воєнних, наукових, науковотехнічних, інформаційних, правових, організаційних, інших заходів

1 Устименко О.В., Сніцаренко П.М., Саричев Ю.О. Державне управління у воєнній сфері як об'єкт термінології та практичної діяльності. Збірник наукових праць НАДУ при Президентові України / за заг. ред. А.П. Савкова. Київ, НАДУ. 2019. Вип. 1. С. 69-74. 
держави щодо підготовки до збройного захисту та ії захист у разі збройної агресії або збройного конфлікту.

У вузькому розумінні: оборона - вид бойових дій військ (сил), що застосовується 3 метою відбиття наступу (ударів) військ (сил) противника... Сутність оборони полягає в поразці угруповань противника... Це досягається нанесенням по них ударів різними видами зброї.

Наведене означає, що в сучасних умовах для України як держави розділяти та розглядати окремо поняття «воєнна сфера» та «сфера оборони» в політичному сенсі, теоретичних напрацюваннях та практичних діях нелогічно і недоцільно.

Оскільки сфера оборони України регламентована Законом України «Про оборону України», то поняття «воєнна сфера» (еквівалентне поняттю «сфера оборони») має узагальнено відображати сутність його положень. Грунтуючись на цьому, можна запропонувати актуальне для України таке визначення: воєнна сфера (сфера оборони) - діяльність органів державної влади, сил оборони, органів місиевого самоврядування, а також підприємств, установ, організаиій $i$ громадян та громадських об'єднань України, яка пов'язана з організацією і проведенням заходів підготовки держави до оборони та веденням оборони держави у разі збройної агресії проти неї.

Таким чином, державне управління у воєнній сфері, як об'єкт практичної діяльності, доцільно розглядати під кутом зору наведеного визначення, розуміючи, що для реалізації цього процесу має діяти відповідна система. Звернемо увагу на особливості функціонування такої системи, що $є$ необхідним для подальших висновків.

Беручи до уваги зазначене i зважаючи на потребу реалізації кібернетичної моделі функціонування системи державного управління у воєнній сфері, про що зокрема наголошено у ході досліджень теоретичних підходів до інформаційного забезпечення у системі державного управління у воєнній сфері фахівцями Центру воєнностратегічних досліджень Національного університету оборони України, необхідно розглядати іiі основні елементи: орган державного управління у воєнній сфері, виконавчий орган, об'єкт управління та орган державного моніторингу (контролю) результатів державного управління (це дії або стан об’єкта управління).

\section{2. Орган державного управління у воснній сфері}

Виходячи із положень Конституції України та законів України «Про національну безпеку України» i «Про оборону України», стає можливим визначення щодо органу державного управління у воєнній сфері (суб'єкта державного управління), який слід вважати сукупним, де одним із органів державного управління є Верховна Рада України, 
а іншим - Президент України. При цьому Верховна Рада України здійснює законодавче регулювання питань сфери оборони та реалізує право на парламентський контроль у цій сфері, а Президент України $\epsilon$ Верховним Головнокомандувачем ЗС України та здійснює керівництво у сфері оборони (отже, у воєнній сфері) шляхом реалізації таких процедур, як видання указів, розпоряджень, наказів та директив, так і поточного або оперативного контролю (моніторингу) стану їх виконання. Це означає, що в Україні діють два контури державного управління у воєнній сфері, які доцільно назвати регуляторним (з боку Верховної Ради України) та процедурним (з боку Президента України).

Оскільки, крім Верховної Ради України, інші суб'єкти воєнної сфери за державним статусом $є$ виконавчими органами, а серед них інститут Президента України визначено керівним у сфері оборони, то, крім нього, інші суб'єкти цієї сфери необхідно вважати виконавчим органом у системі державного управління у воєнній сфері (також сукупним). Отже, цей сукупний виконавчий орган утворюють інші органи державної влади, сили оборони, органи місиевого самоврядування, а також підприємства, установи, організаиії і громадяни та громадські об'єднання України. Ці складники виконавчого органу та результати їх діяльності безпосередньо чи опосередковано є підконтрольними та підзвітними Верховній Раді України і Президенту України.

Тоді на основі вищенаведеного можна пропонувати таке важливе визначення, як: державне управління у воєнній сфері - ие практичний, організуючий вплив держави, який здійснюють Верховна Рада Украйни та Президент України на діяльність органів виконавчої влади, сил оборони, органів місиевого самоврядування, а також підприємств, установ, організачій і громадян та громадських об'єднань Украйни з метою організаиії і проведення заходів підготовки держави до оборони та ведення оборони держави у разі збройної агресії проти неї.

Це визначення дозволяє розуміти роль та місце кожного із суб'єктів воєнної сфери у складному процесі державного управління у цій сфері.

Постає принципове питання щодо сутності об'єкта управління у системі державного управління у воєнній сфері. На перший погляд, об'єктом управління має бути виконавчий орган та його діяльність, що, власне, традиційно i розглядається. Але цілком очевидно, що найважливішим з точки зору визначеної мети управління слід вважати отриманий ефект від цієї діяльності. У нашому випадку цей ефект полягає в досягненні достатньої результативності, по-перше, заходів підготовки держави до оборони, а по-друге, заходів ведення оборони держави у разі збройної агресії проти неї.

У нашому випадку об'єктом управління має бути не сам процес діяльності сукупного виконавчого органу, а результат його діяльності, 
виражений у певних показниках та критеріях. Тому об'єктом управління в системі державного управління у воєнній сфері має бути результативність, причому, на нашу думку, доцільно проводити дослідження двох складників:

а) заходів підготовки держави до оборони (рівень набуття необхідних спроможностей сил оборони);

б) заходів ведення оборони держави у разі збройної агресії проти неї (рівень підготовки та результат ведення операцій і бойових дій сил оборони проти агресора).

Розглядаючи вищезазначені два складники результативності як об'єкта управління в системі державного управління у воєнній сфері, а саме заходи підготовки держави до оборони (рівень набуття необхідних спроможностей сил оборони); заходи ведення оборони держави у разі збройної агресії проти неї (рівень підготовки та результат ведення операцій і бойових дій сил оборони проти агресора), зауважимо, що процеси досягнення позитивної результативності у цих двох складниках суттєво відрізняються як за метою, так і за динамікою протікання i засобами проведення заходів. Аналізуючи заходи підготовки держави до оборони, доходимо висновку, що це планомірні відносно довготривалі заходи переважно мирного часу. А у разі дослідження заходів ведення оборони держави у разі збройної агресії проти неї - переважно динамічні заходи особливого періоду.

Зазначене потребує двох дещо різних схем реалізації кібернетичної моделі функціонування системи державного управління у воєнній сфері та різних систем державного моніторингу (контролю) у системі державного управління у воєнній сфері.

Відповідно до законодавства України ${ }^{2}$ основними суб'єктами здійснення державного моніторингу (контролю) результативності виконання заходів з питань оборони (отже, у воєнній сфері!) визначено Верховну Раду України, Президента України та Кабінет Міністрів України.

Низку важливих функцій державного моніторингу (контролю) 3 питань оборони законодавством України покладено на Міністерство оборони України (МО України), а також Генеральний штаб (ГШ) ЗС України, а окремі функції - на інші центральні органи виконавчої влади, що мають у підпорядкуванні утворені відповідно до законодавства військові формування, розвідувальні та правоохоронні органи, а також на Верховну Раду і Кабінет Міністрів Автономної

2 Закон України «Про національну безпеку України» від 21.06.2018 № 2469-VIII. URL: https://zakon.rada.gov.ua/laws/show/ 2469-19 (дата звернення: 19.06.2019).

Закон України «Про оборону України». Нормативно-правова база у галузі безпеки і оборони України. Київ : Центр дослідження армії, конверсії і роззброєння, 2016. $872 \mathrm{c}$. 
Республіки Крим, місцеві органи виконавчої влади та органи місцевого самоврядування.

Відповідно до повноважень названих суб'єктів державний моніторинг (контроль) у воєнній сфері можливо поділити на два різновиди - загальний та поточний $i$ оперативний. Загальний державний моніторинг (контроль) у воєнній сфері здійснює Верховна Рада України через механізми парламентського контролю у межах, визначених Конституцією України та законом. Поточний i оперативний державний моніторинг (контроль) у воєнній сфері здійснюється іншими суб'єктами контролю у сфері оборони.

Поточний державний моніторинг (контроль) має плановодискретний характер у часі і грунтується на вивченні та оцінці протягом певного часу ситуацій за документованими даними регламентованої звітності «знизу-вверх», а також планових і позапланових перевірок (інспекцій) «зверху-вниз».

Оперативний державний моніторинг (контроль) стосується спостереження процесу протікання динамічних кризових ситуацій (війна або збройний конфлікт, ліквідація за участю суб'єктів сил оборони надзвичайних явищ або проявів тероризму) і реалізується упродовж такої ситуації безперервно у реальному часі для іiї оцінки та прийняття негайних управлінських рішень без обов'язкового розгляду при цьому матеріалів документування динаміки подій, що спричиняють потребу цих рішень.

Президент Украӥни здійснює обидва види моніторингу (контролю) як безпосередньо, так і через механізми Ради національної безпеки і оборони України або створювані ним за необхідності допоміжні органи і служби.

Кабінет Міністрів Украӥни застосовує урядові механізми моніторингу (контролю) 3 питань дотримання законодавства та реалізації державної політики у сфері оборони, а також забезпечення цивільного контролю за діяльністю сил оборони, звітує з цих питань перед Президентом України і Верховною Радою України. Ці урядові механізми не потребують оперативності в масштабі реального часу, а тому реалізуються процедурами поточного моніторингу (контролю).

МО України, інші центральні органи виконавчої влади, що мають у підпорядкуванні утворені відповідно до законодавства військові формування, розвідувальні та правоохоронні органи, здійснюють і забезпечують цивільний контроль у межах своїх повноважень та об'єктивно і своєчасно інформують Верховну Раду України, Президента України (через Раду національної безпеки і оборони України) та Кабінет Міністрів України про стан справ (результативність виконання заходів з питань оборони!) у підпорядкованих 
органах. Процедури реалізуються, як правило, алгоритмами поточного моніторингу (контролю).

Головнокомандувач ЗС Украӥни відповідає за готовність до виконання завдань та безпосереднє військове управління застосуванням ЗС України, а також підпорядкованих йому сил і засобів інших складових частин сил оборони, він підпорядкований ma є підзвітним Президенту Украӥни і Міністру оборони Украӥни. Йому, своєю чергою, підпорядкований ГШ ЗС Украӥни, який здійснює планування оборони держави, застосування ЗС України та сил і засобів інших складників сил оборони та проводить моніторинг (контроль) за виконанням завдань у сфері оборони органами виконавчої влади, органами місиевого самоврядування, а також за підготовкою всіх складників сил оборони та набуття ними необхідних об'єднаних спроможностей. При цьому процедури моніторингу (контролю) ГШ 3С України реалізуються, як правило, алгоритмами поточного моніторингу (контролю).

Головнокомандувачу ЗС України також підпорядковуються та підзвітні:

- командувачі видів, окремих родів військ (сил) ЗС Украӥни, які відповідають за розвиток підпорядкованих їм військ (сил), їх технічне оснащення та всебічне забезпечення, підготовку та готовність до виконання поставлених завдань;

- командувач об'єднаних сил, у підпорядкуванні якого перебуває Об'єднаний оперативний штаб ЗС Украйни (орган управління міжвидовими та міжвідомчими угрупованнями військ (сил)), через який здійснюється моніторинг (контроль) за набуттям об'єднаними силами оперативних (бойових) спроможностей, планування їх застосування та безпосереднє управління під час виконання завдань в операціях (бойових діях). Командувач об'єднаних сил за погодженням 3 Міністром оборони України і Головнокомандувачем ЗС України має право доповідати безпосередньо Президентові Украйни про готовність та хід виконання завдань об’єднаними силами.

\section{3. Схема системи державного управління у воснній сфері}

У цих функціях Головнокомандувач ЗС України, а також Командувач об'єднаних сил реалізують обидва види моніторингу (контролю). Зазначені особливості дозволяють зобразити загальну схему системи державного управління у воєнній сфері, відповідно до чинного законодавства України, стосовно заходів підготовки держави до оборони (рисунок 1). 


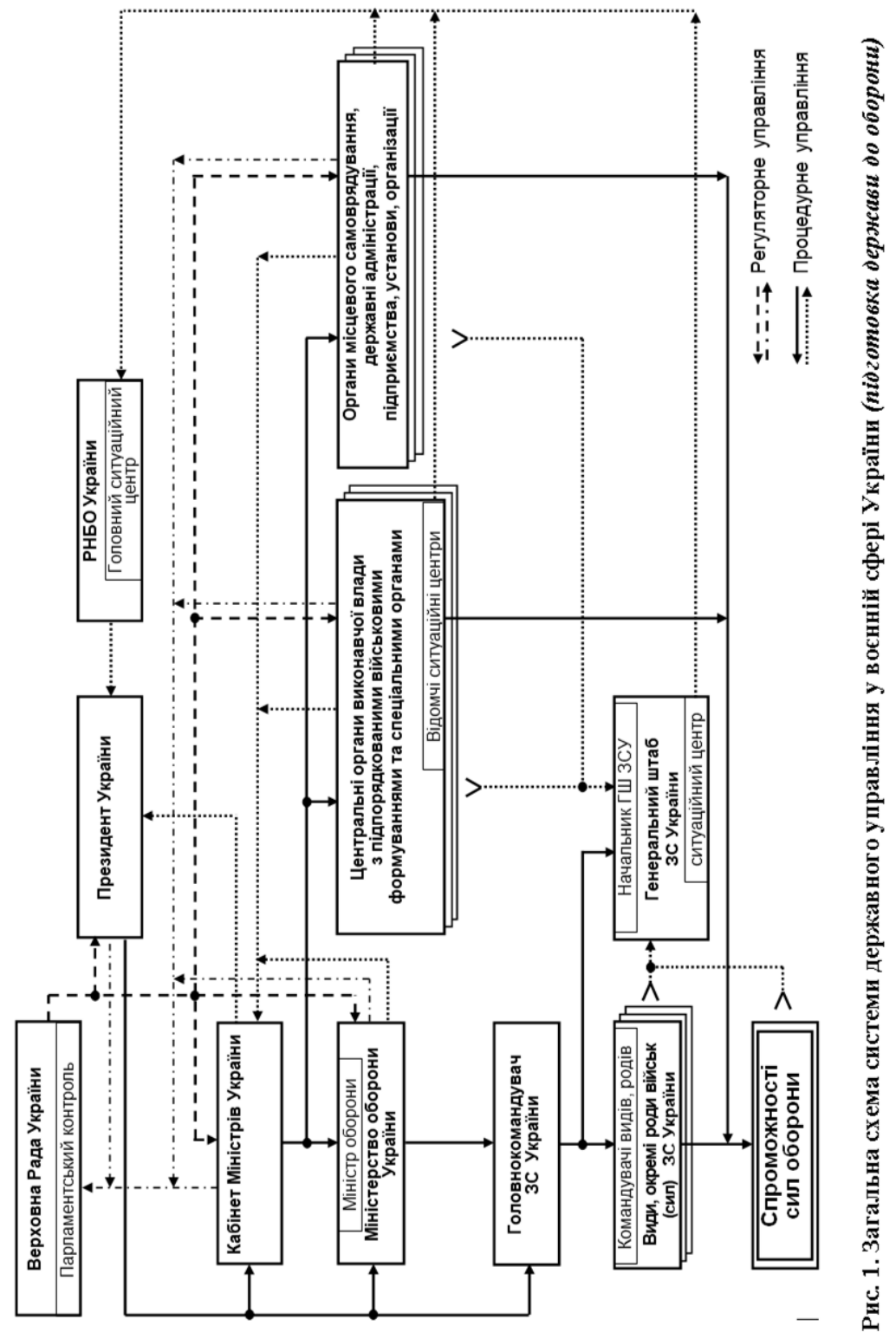


Розгляд схеми свідчить про таке.

Система державного управління у воєнній сфері має не відомчий, а загальнодержавний характер.

Система державного управління у воєнній сфері $\epsilon$ складним утворенням 3 багатьма елементами та паралельно-ісрархічною структурою підпорядкованості i двома базовими контурами державного управління - регуляторним (з боку Верховної Ради України) та процедурним (з боку Президента України). У кожному із цих контурів задіяні одні і ті ж виконавчі елементи.

У системі державного управління у воєнній сфері на кожному ієрархічному рівні підпорядкованості, відповідно до повноважень, діють також локальні контури управління. Таке локальне управління не слід вважати державним (відомчим, військових формувань, установ, організацій тощо), але воно $є$ невід'ємним складником загального процесу державного управління (як наслідок потреби реалізації процесу державного управління). Як приклад зауважимо, що глибина безпосередньо державного управління силами оборони сягає рівня Об'єднаного оперативного штабу ЗС України та Командувача об'єднаних сил, який має право доповіді безпосередньо Президенту України. Управління «вниз» $є$ прерогативою виключно Командувача об'єднаних сил i це вже не державне, а військове управління, результативність якого впливає на загальну результативність державного управління у воєнній сфері.

Зауважимо також на важливості ролі ієрархічно поєднаних відомчих ситуаційних центрів у забезпеченні високої ефективності державного управління у воєнній сфері, особливо у фазі ведення оборони держави, коли постійно виникає потреба в реалізації оперативного державного моніторингу (контролю) шляхом безпосереднього доступу до актуальних інформаційних ресурсів, що формуються в низових ситуаційних центрах, для оперативної оцінки ситуацій та прийняття невідкладних державних рішень.

Реалізація усього складного процесу в системі державного управління у воєнній сфері як у контурах державного рівня, так і в локальних контурах управління нижчого рівня залежить від відповідного інформаиійного забезпечення, яке нині потребує окремого розгляду, вивчення та узагальнення 3 метою використання цих результатів для реалізації адекватних практичних інформаційних дій у сфері оборони держави, що спричиняє важливе актуальне проблемне питання та необхідність його розв'язання.

Отже, система державного управління у воєнній сфері має не відомчий, а загальнодержавний характер. На основі кібернетичного принципу управління визначено основні два елементи системи 
державного управління у воєнній сфері - орган державного управління, який слід вважати сукупним, де однією складовою частиною є Верховна Рада України, а іншою - Президент України та виконавчий орган у цій системі (також сукупний), що становлять вертикаль органів виконавчої влади, сили оборони, органи місцевого самоврядування, а також підприємства, установи, організації і громадяни та громадські об'єднання України.

У попередніх статтях ${ }^{3}$ досліджено лише першу складову частину кібернетичної системи державного управління у воєнній сфері України iii загальну схему у підготовці держави до оборони та проведено аналіз функціонування у цій схемі елементів (суб'єктів) системи державного управління. Перед фахівцями лежить потреба розгляду особливостей реалізації другої складової частини кібернетичної системи державного управління у воєнній сфері України - у разі ведення оборони держави у разі збройної агресії проти неї.

Необхідно зауважити, що всі основні елементи кібернетичного контуру системи державного управління у воєнній сфері визначені та розглянуті в дослідженні ${ }^{4}$ для функції підготовки держави до оборони, а також загальна схема їх взаємодії. Такими елементами цієї системи $є$ сукупний орган державного управління, який утворюють Верховна Рада України та Президент України, сукупний виконавчий орган, що включає всю вертикаль органів виконавчої влади, сили оборони, органи місцевого самоврядування, підприємства, установи, організації і громадян та громадські об'єднання України, а також комплексний механізм державного моніторингу (контролю) результативності державного управління. При цьому якраз рівень результативності державного управління є об'єктом державного управління.

3 Устименко О.В., Сніцаренко П.М., Саричев Ю.О. Державне управління у воєнній сфері як об'єкт термінології та практичної діяльності. Збірник наукових праць НАДУ при Президентові України / за заг. ред. А.П. Савкова. Київ, НАДУ. 2019. Вип. 1. С. 69-74.

Сніцаренко П.М., Саричев Ю.О., Устименко О. В. Сутність та особливості системи державного управління у воєнній сфері у підготовці держави до оборони. Вісник Національної академії державного управління при Президентові України. 2019. № 3. C. 47-52.

${ }^{4}$ Сніцаренко П.М., Саричев Ю.О., Устименко О. В. Сутність та особливості системи державного управління у воєнній сфері у підготовці держави до оборони. Вісник Національної академії державного управління при Президентові України. 2019. № 3. C. 47-52.

Сніцаренко П.М., Саричев Ю.О., Зубков В.П., Устименко О.В. Система державного управління у воєнній сфері у підготовці держави до оборони: сутність та особливості. Науковий часопис Академії національної безпеки. № 1-2 (21-22). Київ : ТОВ «Олександрія-Ф», 2019. С. 95-107. 
У разі збройної агресії проти держави, що нами розглядається, результативністю процесу управління, тобто об'єктом державного управління, є рівень підготовки та результат ведення операиій $і$ бойових дій сил оборони проти агресора. У цьому разі всі елементи кібернетичного контуру системи державного управління у воєнній сфері, які задіяні у процесі реалізації функції підготовки держави до оборони, а також їх розпорядчі, регуляторні та контрольні повноваження залишаються незмінними. Але до сукупності органів виконавчої вертикалі системи включаються інші складники, які мають бути невід'ємними під час реалізації функції захисту держави у разі збройної агресії або збройного конфлікту. Тому є потреба визначення місця і ролі цих інших складників кібернетичного контуру системи державного управління у воєнній сфері.

Відповідно до чинного законодавства України 5 такими елементами стають об'єднані сили (міжвидові або міжвідомчі угруповання військ (сил)), які очолює Командувач об'єднаних сил, у підпорядкуванні якого перебуває Об 'єднаний оперативний штаб ЗС Украйни - орган управління міжвидовими та міжвідомчими угрупованнями військ (сил). Командувач об’єднаних сил підпорядкований та підзвітний Головнокомандувачу ЗС України, чим визначається місце цієї інтегрованої тріади у системі державного управління у воєнній сфері.

Командувач об'єднаних сил через Об'єднаний оперативний штаб ЗС України здійснює як поточний, так і оперативний моніторинг (контроль) за набуттям об'єднаними силами оперативних (бойових) спроможностей, планування їх застосування та безпосереднє управління під час виконання завдань в операціях (бойових діях). Підкреслимо, що у разі збройної агресії проти держави коли переважають динамічні заходи особливого періоду у фазі воєнного часу особливо актуальними стають заходи оперативного моніторингу (контролю) у разі реалізації всіх заходів процесу управління.

Інтегрована тріада - Командувач об'єднаних сил, Об'єднаний оперативний штаб ЗС України та об'єднані сили (міжвидові або міжвідомчі угруповання військ (сил)) - становить основну рушійну (ударну) силу, яка за необхідності захисту держави у разі збройної агресії або збройного конфлікту реалізує накопичений потенціал спроможностей для досягнення результативності державного управління у воєнній сфері (наприклад, відбиття агресії). У цьому полягає головна

5 Закон України «Про національну безпеку України» від 21.06.2018 № 2469-VIII. URL: https://zakon.rada.gov.ua/laws/show/ 2469-19 (дата звернення: 19.06.2019).

Закон України «Про оборону України». Нормативно-правова база у галузі безпеки і оборони України. Київ : Центр дослідження армії, конверсії і роззброєння, 2016. $872 \mathrm{c}$. 
роль тріади як інтегрованого виконавчого елемента у складі сукупного виконавчого органу в системі державного управління у воєнній сфері.

Командувач об'єднаних сил за погодженням 3 Міністром оборони України i Головнокомандувачем ЗС України має право доповідати безпосередньо Президентові України про готовність та хід виконання завдань об'єднаними силами. Таким чином, у цьому разі вертикаль державного управління у воєнній сфері закінчується на рівні Командувача об'єднаних сил, а нижчий рівень управління вже не слід вважати державним, а лише суто військовим управлінням, що $\epsilon$ прерогативою виключно Командувача об'єднаних сил, незважаючи на те, що воно забезпечує продовження загального процесу державного управління (як наслідок потреби реалізації загального процесу державного управління).

Зазначені особливості дозволяють, уточнивши загальну схему системи державного управління у воєнній сфері, що стосується ситуації підготовки держави до оборони, побудувати загальну схему системи державного управління у воєнній сфері стосовно заходів ведення оборони держави у разі збройної агресії проти неї (рисунок 2).

Розгляд цієї схеми, як і під час аналізу схеми системи державного управління у воєнній сфері України щодо підготовки держави до оборони, засвідчує, що система державного управління у воєнній сфері має не відомчий, а загальнодержавний характер. Така система є ще більш розширеним складним утворенням з багатьма елементами та паралельно-ієрархічною структурою підпорядкованості i двома базовими контурами державного управління - регуляторним (з боку Верховної Ради України) та процедурним (з боку Президента України). У кожному із цих контурів задіяні одні і ті ж виконавчі елементи, які забезпечують ведення оборони держави.

Зростає роль ієрархічно поєднаних відомчих ситуаційних центрів у забезпеченні високої ефективності, насамперед оперативності, державного управління у воєнній сфері, особливо у фазі ведення оборони держави, коли постійно виникає потреба в реалізації оперативного державного моніторингу (контролю) шляхом безпосереднього доступу до актуальних інформаційних ресурсів, що формуються в низових ситуаційних центрах, для оперативної оцінки ситуацій та прийняття невідкладних державних управлінських рішень.

Сукупний розгляд наведених схем системи державного управління у воєнній сфері як у фазі підготовки держави до оборони, так і у фазі ведення оборони держави показує, що реалізація державного управління у цій сфері як кібернетичної моделі являє собою складний замкнений інформаційний процес у складі взаємоузгодженої сукупності часткових, але водночас базових інформачійних процесів: 


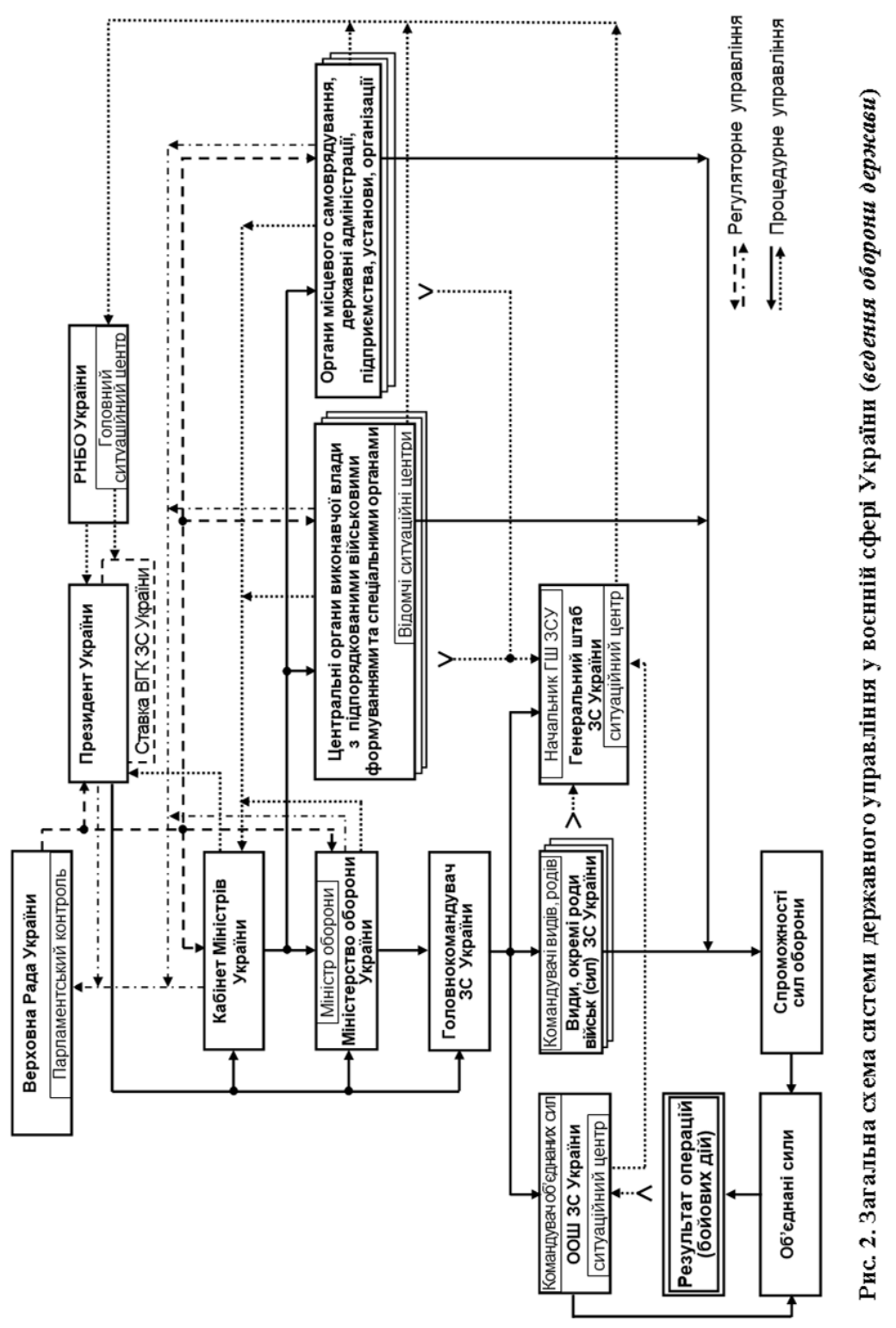


а) формування органом управління ідеї, мети та завдань управління (управлінського рішення) - це результат інтелектуальної роботи цього органу, як правило, викладений у документі, причому будь-якого рівня управління та в будь-якій знаковій формі, тобто за сутністю це інформаційний продукт для подальшого використання, який забезпечує розуміння таких власних дій та дій підлеглих виконавчих органів;

б) донесення управлінського рімення (управлінського впливу) від органу управління до виконавчого органу - це інформаційний процес, що забезпечує передачу управлінського рішення (тобто інформаційного продукту) до виконавчого органу (виконавців) у визначеній формі комунікації та його сприйняття (усвідомлення) ними для підготовки i реалізації таких заходів (дій), спрямованих на об'єкт управління, чутливого до таких впливів (дій);

в) донесення управлінського рішення до об'єкта управління - це управлінський процес, який реалізується виконавчим органом (виконавцями) шляхом певного інформаційного або іншого управлінського впливу, що забезпечує виконання управлінського рішення об'єктом управління (досягнення мети, тобто результативності процесу управління);

г) отримання органом моніторингу (контролю) даних щзодо стану об'єкта управління - це інформаційний процес, який грунтується на комплексному використанні методів усіх видів розвідки, адміністративної та оперативної звітності, а також інспектування структурних елементів (воєнної сфери) для отримання донесень (відомостей), що забезпечує можливість реалізації аналітичного процесу їх структурованої формалізації 3 метою подальшого використання цього отриманого інформаційного продукту для оцінки результативності процесу управління;

г) формування органом моніторингу (контролю) інформації щодо оцінки результативності управління та донесення ї̈ до органу управління для коригування ним поточного управлінського впливу - це інформаційний процес, який полягає в аналітичній обробці комплексу формалізованих, але різнорідних даних та створення на цій основі узагальнених інформаційних продуктів, які забезпечують (дозволяють здійснити) ухвалу судження (оцінку) про стан об'єкта управління (результативність процесу управління), а також передачі цих інформаційних продуктів у визначеній формі комунікації для їх сприйняття (усвідомлення, коригування) органом управління (особою, що приймає рішення). 


\section{ВИСНОВКИ}

Як видно із наведеного, процес державного управління у воєнній сфері є універсальним і являє собою замкнений цикл послідовно пов'язаних різнорідних часткових інформаційних процесів, які спонукають (стимулюють діï) до цілеспрямованого перетворення елементів дійсності воєнної сфери. Це дозволяє стверджувати, що на рівні спрощеного розуміння цю послідовність пов'язаних різнорідних інформаційних процесів (не вдаючись у подробиці їх організації та технічної реалізації!) слід розглядати як суть інформаційного забезпечення всього процесу державного управління, зокрема у воєнній сфері. Зважаючи на те, що теоретичним питанням інформаційного забезпечення у цій галузі досі не приділено досить уваги, то це потребує окремого розгляду, вивчення та узагальнення 3 метою реалізації адекватних практичних інформаційних дій у системі державного управління у воєнній сфері.

На основі вимог законодавства України визначено основні елементи та загальну схему кібернетичного контуру системи державного управління у воєнній сфері під час ведення оборони держави у разі збройної агресії. Це дозволяе найбільш чітко розуміти механізм управління у сфері оборони у реалізації державної функції ведення оборони держави у разі збройної агресії.

Важливим, невід'ємним елементом у системі державного управління у воєнній сфері під час ведення оборони держави є інтегрована тріада - Командувач об'єднаних сил, Об'єднаний оперативний штаб ЗС України та об'єднані сили (міжвидові або міжвідомчі угруповання військ (сил)), яка за необхідності захисту держави у разі збройної агресії або збройного конфлікту доповнює загальну систему державного управління і становить основну рушійну (ударну) силу та реалізує накопичений потенціал спроможностей сил оборони для досягнення результативності державного управління у воєнній сфері, зокрема, відбиття агресії.

Будь-яку функцію у системі державного управління неможливо реалізувати без належного інформаційного забезпечення цього процесу, оскільки управлінський вплив на всіх рівнях системи здійснюється виключно інформацією відповідного характеру і змісту. Тому питання інформаційного забезпечення державного управління, зокрема у воєнній сфері, як такі, що не досить досліджені, потребують більш адекватного теоретичного вивчення та змістового наповнення.

Реалізація всього складного процесу в системі державного управління у воєнній сфері як у контурах державного рівня, так і в локальних контурах управління нижчого рівня залежить від відповідного інформаційного забезпечення, яке сьогодні потребує 
окремого розгляду, вивчення та узагальнення 3 метою використання цих результатів для реалізації адекватних практичних інформаційних дій у сфері оборони держави, що спричиняє важливе актуальне проблемне питання та необхідність його розв'язання.

За законами кібернетики будь-яка функція управління (в тому числі у соціальних системах) реалізується виключно інформаційним шляхом, а тому очевидно, що процес всякого управління, зокрема соціального, яким є державне управління, потребує реалізації низки інформаційних процесів, що справляють вплив на всі елементи в конкретному механізмі державного управління. Тому механізми державного управління по суті мають інформаційну природу. А сукупність цих інформаційних процесів власне i пронизує весь замкнений контур державного управління. При цьому його сутність полягає, 3 одного боку, у необхідності формування ідеї, мети і завдань державного управління та їх донесення від органу державного управління до елементів системи шляхом певного організуючого інформаційного впливу, а з іншого - в можливості отримання органом державного управління зворотної інформації для контролю процесу управління та корегування організуючого інформаційного впливу, що і потребує реалізації загальної схеми державного управління.

\section{АНОТАЦІЯ}

Такий підхід 3 необхідними інформаційними процесами має бути реалізований в усіх механізмах державного управління для досягнення цілей держави, визначених Конституцією України, зокрема, цілей захисту суверенітету і територіальної цілісності України. Досягнення цієї цілі пов'язане із державним управлінням у воєнній сфері, в галузі, яка об'єднує різнорідну діяльність у державі в інтересах сил оборони.

Будь-яку функцію в системі державного управління неможливо реалізувати без належного інформаційного процесу, оскільки управлінський вплив здійснюється виключно інформацією відповідного характеру і змісту безпосередньо за допомогою наявних інформаційних ресурсів, що продукуються елементами інформаційної інфраструктури держави.

Запропоноване визначення механізму реалізації управлінських впливів системи державного управління у воєнній сфері дозволяє зрозуміти інформаційну природу цього соціального явища, розкриває його сутність та важливість, а також його роль і місце у сучасній системі державного управління, зокрема у воєнній сфері.

Подальші дослідження доцільно спрямувати на побудову механізму реалізації управлінських впливів у системі державного управління у воєнній сфері, що має функціонувати за стандартами НАТО, а також 
на його сутність, елементи, їх місце, роль та особливості взаємодії у ході управлінського процесу.

\section{ЛIТЕРАТУРА}

1. Устименко О.В., Сніцаренко П.М., Саричев Ю.О. Державне управління у воєнній сфері як об'єкт термінології та практичної діяльності. Збірник наукових прачь НАДУ при Президентові України I за заг. ред. А.П. Савкова. Київ, НАДУ. 2019. Вип. 1. С. 69-74.

2. Закон України «Про національну безпеку України» від 21.06.2018 № 2469-VIII. URL: https://zakon.rada.gov.ua/laws/show/ 2469-19 (дата звернення: 19.06.2019).

3. Закон України «Про оборону України». Нормативно-правова база у галузі безпеки і оборони України. Київ : Центр дослідження армії, конверсії і роззброєння, 2016. 872 с.

4. Сніцаренко П.М., Саричев Ю.О., Устименко О.В. Сутність та особливості системи державного управління у воєнній сфері у підготовці держави до оборони. Вісник Національної академії державного управління при Президентові Украӥни. 2019. № 3. С. 47-52.

5. Сніцаренко П.М., Саричев Ю.О., Зубков В.П., Устименко О.В. Система державного управління у воєнній сфері у підготовці держави до оборони: сутність та особливості. Науковий часопис Академії національної безпеки. № 1-2 (21-22). Київ : ТОВ «Олександрія-Ф», 2019. C. 95-107.

\section{Information about the author: Ustymenko O. V.,}

Ph.D in Public Administration, Senior Researcher, Associate Professor at the Department of Globalistics, European Integration and National Security Management National Academy for Public Administration under the President of Ukraine 20, Anton Tsedyk str., Kyiv, 03057, Ukraine

ORCID ID: 00000-0002-0003-0790 